\title{
New Labdane Diterpenes from the Stem Bark of Larix laricina
}

\author{
André Pichette, Serge Lavoie, Pierre Morin, Vakhtang Mshvildadze, Maxime Lebrun, and \\ Jean LEGAULT* \\ LASEVE, Département des Sciences Fondamentales, Université du Québec à Chicoutimi; 555 Bd Université, Chicoutimi, \\ Qc, Canada, G7H 2B1. Received March 29, 2006; accepted July 19, 2006
}

Two new labdane diterpenes, cis-19-hydroxyabienol (1) and 8 $\alpha$-hydroxy-12Z,14-labdadien-19-al (2), along with another labdane described for the first time in the genus Larix, 19-acetoxy-13S-hydroxy-8(17),14-labdadiene (3) and a stilbene, 3-methoxy-3,3',5'-trihydroxystilbene (4), were isolated from the stem bark of Larch (Larix laricina). Their structures were established by standard chemical and spectroscopic methods. Compounds 2 and 3 were shown to be moderately cytotoxic against A-549, DLD-1 and normal skin fibroblast cell lines, WS1. Compound 1 was found to be selectively active against colon carcinoma cell lines, DLD-1.

Key words Larix laricina; labdane; cytotoxic; isolation; phenolic compound; NMR

Plant natural products represent an important source of new therapeutic agents. It is estimated that $60 \%$ of anticancer compounds approved between 1981 and 2002 were of natural origin. ${ }^{1)}$ Until now, very few biopharmaceutical studies were undertaken on plant species of the boreal forest of eastern Canada, even though this forest represents a major resource of the country. ${ }^{2)}$ In addition, this natural resource plays an important role in the traditional medicine of First Nations communities from Quebec., ${ }^{3,4)}$ It is for these reasons that our research group has undertaken the evaluation of the biopharmaceutical potential of several plants found in the Quebec boreal forest. In the course of our studies, we observed that the chloroform extract of the bark of the Larch tree Larix laricina Du Roi K. Koch (Pinaceae) possesses in vitro cytotoxic activity (data not shown). To our knowledge, no other study was carried out on the cytotoxic activity of this tree. Moreover, the chemical composition of the bark of this conifer was not reported. However, Von Rudloff ${ }^{5,6}$ identified some of the extractables from the heartwood and several volatile compounds present in the twigs and leaves. Also, phenolic glycosides and aglycones where reported in the needles by Niemann. ${ }^{7,8)}$ Mills ${ }^{9}$ reported the presence of diterpenes in the oleoresins of several varieties of larch.

Fractionation of the chloroform extract of the bark of Larix laricina resulted in the isolation of two new diterpenes, cis-19-hydroxyabienol (1) and $8 \alpha$-hydroxy-12Z,14labdadien-19-al (2), and two known compounds identified as 19-acetoxy-13S-hydroxy-8(17),14-labdadiene (3), and 3methoxy-3,3',5'-trihydroxystilbene (rhapontigenin) (4). No report was found indicating the presence of these substances in the genus Larix. This paper describes the isolation of compounds $1-4$ and the elucidation of the structure of new compounds $\mathbf{1}, \mathbf{2}$. In addition, the cytotoxic activities of the isolated compounds were evaluated.

\footnotetext{
Experimental

General Melting points were determined on a Gallenkamp melting point apparatus. Optical rotations were obtained on a Jasco DIP-360 digital polarimeter. FTIR spectra were measured on a Perkin-Elmer Spectrum One Instrument using $\mathrm{KBr}$ disks. NMR spectra where recorded at $292 \mathrm{~K}$ on a Bruker Avance 400 operating at $400.13 \mathrm{MHz}$ for ${ }^{1} \mathrm{H}$ and $100.61 \mathrm{MHz}$ for ${ }^{13} \mathrm{C}$ and using a $5 \mathrm{~mm}$ QNP probe including a z-gradient coil. Chemical shifts are reported in $\mathrm{ppm}$ and referenced to residual proton solvent signals. ${ }^{10}$ ) High-resolution mass spectra were acquired with an Applied Biosystems QSTAR XL Hybrid LC/MS/MS system.
}

Analytical HPLC-MS were performed on an Agilent 1100 series HPLCDAD-MS system. A Zorbax Eclipse XDB-C18 column $(5 \mu \mathrm{m}, 150 \times$ $4.6 \mathrm{~mm}$ ) maintained at $20^{\circ} \mathrm{C}$ was utilised. The mobile phase consisted of (A) $\mathrm{pH} 4$ aqueous formic acid and (B) acetonitrile using an isocratic elution of $55 \% \mathrm{~B}$. The flow rate was $0.8 \mathrm{ml} / \mathrm{min}$. Agilent G1315B diode array detector was utilised for UV detection. The UV spectra were recorded from 190 to $400 \mathrm{~nm}$. An Agilent mass selective detector (VL model) equipped with an atmospheric chemical ionisation source (APCI) was employed for MS detection. All mass spectra were acquired in the positive ion mode. The full scan mass spectrum was recorded over the range of $m / z 100-1000$. Temperature of the drying gas $\left(\mathrm{N}_{2}\right)$ was $300^{\circ} \mathrm{C}$ with a gas flow rate of $41 / \mathrm{min}$ and a nebulising pressure of $40 \mathrm{psi}$. The ionisation voltage was $3000 \mathrm{~V}$ and the corona current was $4 \mu \mathrm{A}$.

Semi-preparative HPLC separation was achieved on an Agilent 1100 series system. A Zorbax ODS-C18 $(7 \mu \mathrm{m}, 21.2 \times 250 \mathrm{~mm})$ was utilised. The mobile phase consisted of (A) $\mathrm{pH} 3.5$ aqueous formic acid and (B) methanol using a gradient elution of 50 to $100 \%$ B for $30 \mathrm{~min}$. The flow rate was $17 \mathrm{ml} / \mathrm{min}$. An Agilent G1365B multiple wavelength detector was utilised for UV detection. The fractions were collected with an Agilent G1364A automatic fraction collector.

HPLC grade acetonitrile (EMD, Canada) was used for HPLC analysis. Reagent grade (Anachemia, Canada) hexanes, ethyl acetate, chloroform and methanol were used for the extraction and separation of compounds $1-4$. The adsorbent for open glass column chromatography was silica gel Ultra Pure ( $40-63 \mu \mathrm{m}$, Silicycle, Quebec, Canada) and $\mathrm{C}_{18}$ reversed phase silica
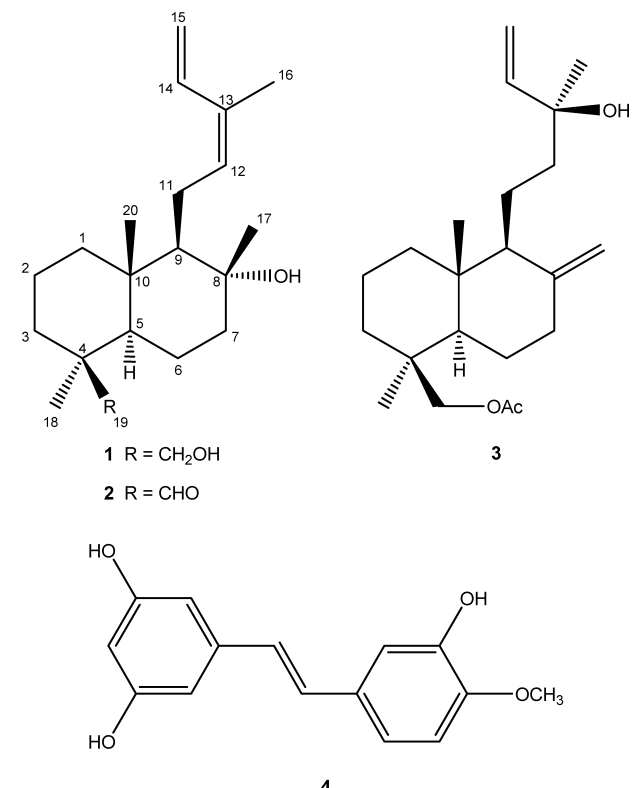

Fig. 1. Structures of Compounds $\mathbf{1}-\mathbf{4}$ 
gel Ultra Pure (40- $63 \mu \mathrm{m}$, Silicycle, Quebec, Canada). Aluminum sheets of silica gel Ultra Pure $(250 \mu \mathrm{m}$ thickness, F-254 indicator, Silicycle, Quebec, Canada) were used for TLC. The solvent systems used for TLC elution was $\mathrm{CHCl}_{3}-\mathrm{MeOH} 20: 1$ or $\mathrm{CHCl}_{3}-$ EtOAc $40: 1$ and spots where developed by spraying with $\mathrm{H}_{2} \mathrm{SO}_{4} 20 \%$ in methanol followed by heating at $110^{\circ} \mathrm{C}$ for $3-$ 5 min.

Plant Material The bark of Larix laricina was collected in May 2003, in La Baie, Québec, Canada and authenticated by Mr. Patrick Nadeau. A voucher specimen (No. 0493197) has been deposited in the herbarium Louis-Marie of Laval University, Québec, Canada.

Extraction and Isolation The air-dried powdered bark $(2 \mathrm{~kg})$ of Larix laricina was extracted with hot $\mathrm{CHCl}_{3}$ (151). Evaporation of the solvent under reduced pressure $\left(30^{\circ} \mathrm{C}\right)$ provided a dark green extract $(221.4 \mathrm{~g}$, $11.1 \%$ from dried bark). Normal phase silica gel column chromatography [hexanes/EtOAc $(10: 1-2: 1-1: 1)]$ of the crude extract $(105 \mathrm{~g})$ gave five fractions [F1 (43.4 g), F2 (15.6 g), F3 (13.2 g), F4 (4.3 g) and F5 (19.7 g)]. F2 was separated by silica gel column chromatography $\left[\mathrm{CHCl}_{3} / \mathrm{EtOAc}\right.$ $(40: 1)$ ] to give 3 (217.3 mg) and impure 2 (109.8 mg). The latter compound was purified by reversed-phase column chromatography $\left[\mathrm{MeOH} / \mathrm{H}_{2} \mathrm{O}(4: 1)\right]$ to give pure $2(9.8 \mathrm{mg})$. F3 was separated by silica gel column chromatography $\left[\mathrm{CHCl}_{3} / \mathrm{MeOH}(20: 1)\right]$ and gave a yellow oil $(2.0 \mathrm{~g})$ which was crystallized with $\mathrm{CHCl}_{3}$ to give $1(417.4 \mathrm{mg})$. F4 was separated on silica gel column chromatography $\left[\mathrm{CHCl}_{3} / \mathrm{MeOH}(20: 1)\right]$ to give impure $4(237.5 \mathrm{mg})$ This compound was purified by semi-preparative HPLC to give pure 4 $(41.0 \mathrm{mg})$.

cis-19-Hydroxyabienol (1): White needles; mp $110-113^{\circ} \mathrm{C} ; R f=0.12$ $\left[\mathrm{SiO}_{2}\right.$, toluene/EtOAc 85:15]; $[\alpha]_{\mathrm{D}}^{25}-17^{\circ}\left(c=0.5, \mathrm{CHCl}_{3}\right) ; \mathrm{UV}(\mathrm{MeOH})$ $\lambda_{\max }$ nm: 236; IR (KBr) cm ${ }^{-1}: 3488,3228,2921,2873,1643,1468,1388$, 1160, 1014, 933, 899; HR-ESI-MS: $[\mathrm{M}+\mathrm{Na}]^{+}$329.2455, Calcd for $\mathrm{C}_{20} \mathrm{H}_{34} \mathrm{O}_{2} \mathrm{Na}, 329.2457$; APCI-MS $m / z=289[\mathrm{M}-\mathrm{OH}]{ }^{+} ;{ }^{1} \mathrm{H}-$ and ${ }^{13} \mathrm{C}-\mathrm{NMR}$ : see Table 1 .

$8 \alpha$-Hydroxy-12Z,14-labdadien-19-al (2): Colourless oil; $R f=0.32\left[\mathrm{SiO}_{2}\right.$, toluene/EtOAc $85: 15]$; $[\alpha]_{\mathrm{D}}^{25}-35^{\circ}\left(c=0.2, \mathrm{CHCl}_{3}\right)$; UV (MeOH) $\lambda_{\max } \mathrm{nm}$ : 238; IR (KBr) cm $\mathrm{cm}^{-1}$ : 3426, 2922, 1716, 1456, 1384, 1163, 1081; APCI-MS $m / z 287[\mathrm{M}-\mathrm{OH}]^{+}, 259[\mathrm{M}-\mathrm{OH}-\mathrm{CHO}]^{+}, 223\left[\mathrm{M}-\mathrm{OH}-\mathrm{C}_{5} \mathrm{H}_{7}\right]^{+} ;{ }^{1} \mathrm{H}-$ and ${ }^{13}$ C-NMR: see Table 1.

Synthesis of 2 from $1^{11)}$ To a solution of pyridinium dichromate (PDC,
$100 \mathrm{mg}$ ) in dichloromethane $(2 \mathrm{ml})$ was added dropwise a solution containing the hydroxylabdane (1) $(70 \mathrm{mg})$. The resulting mixture was stirred at room temperature during $8 \mathrm{~h}$. The excess reagent was filtered onto Florisil and the solution was evaporated to give a colourless oil. The oil was chromatographed on CC over silica gel [hexanes/EtOAc $(3: 1)$ ] affording the synthetic ladbane $2(19.1 \mathrm{mg}, 27.5 \%)$. NMR spectra of the synthetic product were perfectly superimposable with those of the natural labdane (2).

Cell Culture Cell lines A-549 (human lung carcinoma), DLD-1 (human colon adenocarcinoma) and WS1 (normal skin human fibroblast) were obtained from the American Type Culture Collection (ATCC). Cells were maintained at $37{ }^{\circ} \mathrm{C}$ in a $5 \% \mathrm{CO}_{2}$ atmosphere. Both cell lines were grown in minimum essential medium complete with Earle's salts and L-glutamine and supplemented with $10 \%$ fetal bovine serum (Hyclone), vitamins (1X), penicillin (100 I.U/ml) and streptomycin $(100 \mu \mathrm{g} / \mathrm{ml})$, essential amino acids (1X) and sodium pyruvate (1X) (Mediatech Cellgro, VA, U.S.A.).

Cytotoxicity Assay Exponentially growing cells were plated in 96-well microplates (BD Falcon) at a density of $5 \times 10^{3}$ cells per well in $100 \mu \mathrm{l}$ of culture medium and were allowed to adhere for $16 \mathrm{~h}$ before treatment. Increasing concentrations of each compound in the appropriate solvent (DMSO-MeOH 50:50 for compounds 1-3 and $\mathrm{MeOH}$ for compound 4) were then added $(100 \mu \mathrm{l}$ per well). The final concentration of solvent in the culture medium was maintained at $0.5 \%$ (volume/volume) to avoid solvent toxicity. The cells were incubated for $48 \mathrm{~h}$ in the presence or absence of compounds. Cytotoxicity was assessed using resazurin ${ }^{12)}$ on an automated 96-well Fluoroskan Ascent F1TM plate reader (Labsystems) using excitation and emission wavelengths of 530 and $590 \mathrm{~nm}$, respectively. Fluorescence was proportional to the cellular metabolic activity in each well. Survival percentage was defined as the fluorescence in experimental wells compared to that in control wells after subtraction of blank values. Cytotoxicity results were expressed as mean \pm standard deviation and represent the concentration inhibiting $50 \%$ of the cell growth $\left(\mathrm{IC}_{50}\right)$. Each experiment was carried out in triplicate.

\section{Results and Discussion}

Compound 1 was obtained as white needles in a yield of $0.02 \%$. The molecular formula of $\mathbf{1}\left(\mathrm{C}_{20} \mathrm{H}_{34} \mathrm{O}_{2}\right)$ was estab-

Table 1. NMR Assignments of Compounds 1 and 2

\begin{tabular}{|c|c|c|c|c|}
\hline \multirow{2}{*}{ Position } & \multicolumn{2}{|c|}{1} & \multicolumn{2}{|c|}{2} \\
\hline & $\delta_{\mathrm{C}}$ & $\delta_{\mathrm{H}} \operatorname{Mult}(J=\mathrm{Hz})$ & $\delta_{\mathrm{C}}$ & $\delta_{\mathrm{H}} \operatorname{Mult}(J=\mathrm{Hz})$ \\
\hline \multirow[t]{2}{*}{1} & $40.3 \mathrm{t}$ & $0.99 \mathrm{~m}(\alpha)$ & $39.6 \mathrm{t}$ & $1.00 \mathrm{~m}(\alpha)$ \\
\hline & & $1.71 \mathrm{~m}(\beta)$ & & $1.74 \mathrm{~m}(\beta)$ \\
\hline \multirow[t]{2}{*}{2} & $18.3 \mathrm{t}$ & $1.44 \mathrm{~m}(\beta)$ & $18.6 \mathrm{t}$ & $1.48 \mathrm{~m}(\beta)$ \\
\hline & & $1.55 \mathrm{~m}(\alpha)$ & & $1.62 \mathrm{~m}(\alpha)$ \\
\hline \multirow[t]{2}{*}{3} & $35.6 \mathrm{t}$ & $0.96 \mathrm{~m}(\alpha)$ & $34.3 \mathrm{t}$ & $1.03 \mathrm{~m}(\alpha)$ \\
\hline & & $1.77 \mathrm{~m}(\beta)$ & & $2.12 \mathrm{~m}(\beta)$ \\
\hline 4 & $38.7 \mathrm{~s}$ & - & $48.5 \mathrm{~s}$ & - \\
\hline 5 & $56.8 \mathrm{~d}$ & $1.11 \mathrm{dd}(12.3,2.0)$ & $56.6 \mathrm{~d}$ & $1.30 \mathrm{dd}(12.3,2.0)$ \\
\hline \multirow[t]{2}{*}{6} & $20.6 \mathrm{t}$ & $1.30 \mathrm{~m}(\beta)$ & $20.1 \mathrm{t}$ & $1.63 \mathrm{~m}(\beta)$ \\
\hline & & $1.74 \mathrm{~m}(\alpha)$ & & $1.96 \mathrm{~m}(\alpha)$ \\
\hline \multirow[t]{2}{*}{7} & $44.4 \mathrm{t}$ & $1.40 \mathrm{~m}(\alpha)$ & $44.0 \mathrm{t}$ & $1.45 \mathrm{~m}(\alpha)$ \\
\hline & & $1.85 \mathrm{dt}(12.1,3.0)(\beta)$ & & $1.93 \mathrm{~m}(\beta)$ \\
\hline 8 & $74.3 \mathrm{~s}$ & - & $73.9 \mathrm{~s}$ & - \\
\hline 9 & $62.3 \mathrm{~d}$ & $1.33 \mathrm{~m}$ & $60.9 \mathrm{~d}$ & $1.36 \mathrm{dd}(6.4,4.5)$ \\
\hline 10 & $38.9 \mathrm{~s}$ & - & $39.3 \mathrm{~s}$ & - \\
\hline \multirow[t]{2}{*}{11} & $23.4 \mathrm{t}$ & $2.20 \mathrm{~m}$ & $23.5 \mathrm{t}$ & $2.19 \mathrm{~m}$ \\
\hline & & $2.43 \mathrm{~m}$ & & $2.43 \mathrm{~m}$ \\
\hline 12 & $133.7 \mathrm{~d}$ & $5.49 \mathrm{t}(7.4)$ & $133.2 \mathrm{~d}$ & 5.49 brt (7.6) \\
\hline 13 & $131.1 \mathrm{~s}$ & - & $131.5 \mathrm{~s}$ & - \\
\hline 14 & $133.6 \mathrm{~d}$ & 6.88 ddd $(17.3,10.8,0.8)$ & $133.5 \mathrm{~d}$ & $6.85 \mathrm{dd}(17.3,10.8)$ \\
\hline $15 E$ & $114.1 \mathrm{t}$ & $5.21 \mathrm{~d}(17.3)$ & $114.3 \mathrm{t}$ & $5.21 \mathrm{brd}(17.3)$ \\
\hline $15 Z$ & & $5.12 \mathrm{~d}(10.8)$ & & 5.13 br d $(10.8)$ \\
\hline 16 & $20.1 \mathrm{q}$ & $1.80 \mathrm{brs}$ & $20.1 \mathrm{q}$ & 1.80 br s \\
\hline 17 & $24.5 \mathrm{q}$ & $1.18 \mathrm{~s}$ & $24.7 \mathrm{q}$ & $1.22 \mathrm{~s}$ \\
\hline 18 & $27.2 \mathrm{q}$ & $0.98 \mathrm{~s}$ & $24.4 \mathrm{q}$ & $1.02 \mathrm{~s}$ \\
\hline \multirow[t]{2}{*}{19} & $65.5 \mathrm{t}$ & $3.69 \mathrm{~d}(11.1)$ & $205.6 \mathrm{~d}$ & $9.73 \mathrm{~s}$ \\
\hline & & $3.44 \mathrm{~d}(11.1)$ & & \\
\hline 20 & $16.1 \mathrm{q}$ & $0.83 \mathrm{~s}$ & $14.4 \mathrm{q}$ & $0.71 \mathrm{~s}$ \\
\hline
\end{tabular}


lished by HR-ESI-MS $[\mathrm{M}+\mathrm{Na}]^{+}$329.2455. The IR spectrum showed absorptions for hydroxyl groups $\left(3488 \mathrm{~cm}^{-1}\right)$ and double bonds $\left(1643,1468,1388 \mathrm{~cm}^{-1}\right) .{ }^{1} \mathrm{H}-,{ }^{13} \mathrm{C}-\mathrm{NMR}$ and DEPT spectra revealed four methyls, eight methylenes including a terminal double bond and a primary alcohol, four methines including two olefinics and four quaternary carbons including an olefinic and a hydroxyl group (Table 1). Compound 1 was found strongly similar to an already described labdane diterpene. ${ }^{13)}$ The COSY cross-peak between both $\mathrm{H}$ $15(\delta 5.21,5.12)$ and $\mathrm{H}-14(\delta 6.88)$ suggested that the monosubstituted terminal double bond is part of a side chain. Also, the HMBC cross-peaks between H-14 $(\delta$ 6.88) and C-12 $(\delta$ $133.7), \mathrm{C}-13$ ( $\delta$ 131.1), C-16 ( $\delta$ 20.1) showed that the two double bonds are conjugated and that the methyl group is attached to $\mathrm{C}-13$. The attachment of the lateral chain on C-9 is confirmed by the COSY cross-peaks between H-11 ( $\delta$ 2.20, $2.43)$ and $\mathrm{H}-9(\delta 1.33)$. The HMBC cross-peaks between $\mathrm{H}-$ $17(\delta 1.18)$ and $\mathrm{C}-7(\delta 44.4), \mathrm{C}-8(\delta 74.3), \mathrm{C}-9(\delta 62.3)$ indicated that a tertiary alcohol is attached to the same carbon as the methyl at C- 8 . The cross-peaks between $\mathrm{H}-18(\delta 0.98)$ and $\mathrm{C}-3(\delta 35.6), \mathrm{C}-4(\delta 38.7), \mathrm{C}-5(\delta$ 56.8), C-19 $(\delta$ 65.5) in the HMBC spectrum suggested that the secondary alcohol group was bonded to C-4. The stereochemistry of $\mathbf{1}$ was determined by 2D NOESY spectrum (Fig. 2). Firstly, a crosspeak between H-16 $(\delta$ 1.80) and H-12 $(\delta$ 5.49) showed the cis configuration for the inner double bond. Also, crosspeaks between $\mathrm{H}-11(\delta 2.20,2.43)$ and $\mathrm{H}-17(\delta 1.18), \mathrm{H}-20$ ( $\delta 0.83$ ) showed that all these groups are positioned on the same side. The primary alcohol group showed also a $\beta$ configuration, confirmed by the cross-peak between H-19 $(\delta$ $3.44,3.69)$ and $\mathrm{H}-20(\delta 0.83)$. Therefore, the structure of 1 was identified as cis-19-hydroxyabienol.

Compound $\mathbf{2}$ was obtained as a colourless oil in a yield of $0.0005 \%$. The molecular formula of 2 was established as $\mathrm{C}_{20} \mathrm{H}_{32} \mathrm{O}_{2}$ on the basis of LC-MSD and ${ }^{13} \mathrm{C}-\mathrm{NMR}$ spectroscopy. The IR spectrum showed absorptions for an aldehyde $\left(1713 \mathrm{~cm}^{-1}\right)$, hydroxyl groups $\left(3433 \mathrm{~cm}^{-1}\right)$ and double bonds $\left(1645,1452,1384,753 \mathrm{~cm}^{-1}\right)$. NMR spectra of compound $\mathbf{2}$ was found to be strongly similar to compound $\mathbf{1}$ with the only exception being that an aldehyde group was present in place of a primary alcohol (Table 1). Therefore, the structure of 2 was identified as $8 \alpha$-hydroxy-12Z,14-labdadien-19-al. To further confirm the structure of $\mathbf{2}$, the alcohol function of compound $\mathbf{1}$ was oxidized with PDC to the corresponding aldehyde. The spectrum of the synthetic compound was perfectly superimposable with the spectrum of the natural analogue. However, the absolute configuration of compounds 1,2 has not been determined yet.

The other compounds isolated were identified as the known 19-acetoxy-13S-hydroxylabda-8(17),14-diene (3), ${ }^{14}$ and rhapontigenin $(4)^{15)}$ by comparing their spectral data with literature values. To our knowledge, this is the first report of the presence of these compounds in the genus Larix.

Compounds $\mathbf{1}-\mathbf{4}$ were evaluated for their in vitro cytotoxic activities against human lung cancer (A-549), human colorectal cancer (DLD-1) and normal skin fibroblast cells (WS1). The results, presented in Table 2, are expressed as the concentration inhibiting $50 \%$ of the cell growth $\left(\mathrm{IC}_{50}\right)$. Antitumor agents, carmustine, chlorambucil and carboplatin were used as a positive control. Only carboplatin is clinically used in lung and colorectal cancer treatments. The $\mathrm{IC}_{50}$ ranged

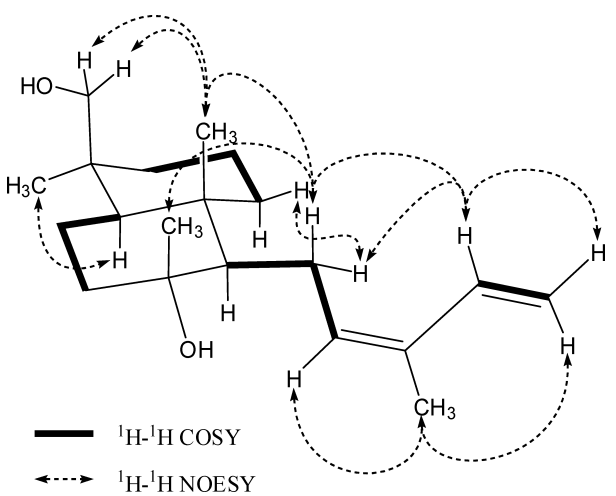

Fig. 2. The Key ${ }^{1} \mathrm{H}-{ }^{1} \mathrm{H}$ COSY and ${ }^{1} \mathrm{H}-{ }^{1} \mathrm{H}$ NOESY Correlations of Compound 1

Table 2. Cytotoxic Activities of Compounds 1-4 against A-549 Lung Carcinoma Cells, DLD-1 Colon Carcinoma Cells and Normal Skin Fibroblasts, WS1

\begin{tabular}{lccc}
\hline \hline \multirow{2}{*}{ Compounds } & \multicolumn{3}{c}{$\mathrm{IC}_{50}(\mu \mathrm{M}, n=3)^{a)}$} \\
\cline { 2 - 4 } & $\mathrm{A} 549$ & $\mathrm{DLD}-1$ & $\mathrm{WS} 1$ \\
\hline Carmustine & $40 \pm 10$ & $50 \pm 10$ & $26 \pm 4$ \\
Chlorambucil & $11 \pm 1^{b)}$ & $14 \pm 4^{b)}$ & $40 \pm 10$ \\
Carboplatin & $63 \pm 6$ & $130 \pm 20$ & n.d..$^{c}$ \\
$\mathbf{1}$ & $>200$ & $37 \pm 3^{b)}$ & $>200$ \\
$\mathbf{2}$ & $44 \pm 5$ & $50 \pm 20$ & $32 \pm 1$ \\
$\mathbf{3}$ & $59 \pm 4$ & $50 \pm 2$ & $60 \pm 10$ \\
$\mathbf{4}$ & $>200$ & $>200$ & $>200$ \\
\hline
\end{tabular}

a) Concentration inhibiting fifty percent of cell growth $\left(\mathrm{IC}_{50}\right)$ were the means of triplicates \pm standard deviations. b) Significantly more sensitive than fibroblasts (WS1); $p \leq 0.05$, Student $t$-test. c) Not determined.

from 26 to $50 \mu \mathrm{M}$ for carmustine and from 11 to $40 \mu \mathrm{M}$ for chlorambucil in all cell lines tested, whereas the $\mathrm{IC}_{50}$ of carboplatin was from $63 \pm 6 \mu \mathrm{M}$ for A-549 and $130 \pm 20 \mu \mathrm{M}$ for DLD-1. The compounds 2 and $\mathbf{3}$ were found to be active against $\mathrm{A}-549$ and DLD-1 with $\mathrm{IC}_{50}$ ranging from 32 to $60 \mu \mathrm{M}$. However, these compounds were also cytotoxic against WS1. In contrast, compound 1 was found to be inactive $\left(\mathrm{IC}_{50}>200 \mu \mathrm{M}\right)$ against WS1 and A-549 but active against DLD-1 $\left(\mathrm{IC}_{50}=37 \pm 3 \mu \mathrm{M}\right)$ suggesting that 1 is selective. Finally, compound $\mathbf{4}$ was found to be inactive against all cell lines tested.

Acknowledgments The authors are grateful to J. Ross for technical assistance and P. Nadeau for plant identification. We thank Dr. N. Voyer and M. Tremblay from Laval University for polarimeter measurements. We thank B. Keller of Toronto University for HR-ESI-MS measurements. This work was supported by Action Concertée FQRNT-Fonds de la recherche forestière du Saguenay-Lac-Saint-Jean.

\section{References}

1) Newman D. J., Cragg G. M., Snader K. M., J. Nat. Prod., 66, $1022-$ 1037 (2003).

2) Portrait forestier des régions du Saguenay_Lac Saint-Jean et du Nord du Québec, Ministère des ressources naturelles, de la faune et des parcs, Québec, 2004.

3) Moermann D. E., "Native American Ethnobotany," Timbre Press, Portland, OR, 1998.

4) Black M. J., "Algonquin Ethnobotany: An Interpretation of Aboriginal Adaptation in Southwestern Quebec," National Museum of Canada, 1980 .

5) Nair G. V., von Rudloff E., Can. J. Chem., 37, 1608-1613 (1959) 
6) von Rudloff E., J. Nat. Prod., 50, 317-321 (1987).

7) Niemann G. J., Phytochemistry, 7, 2101-2103 (1969).

8) Niemann G. J., Bekooy R., Phytochemistry, 10, 893 (1971).

9) Mills J. S., Phytochemistry, 12, 2407-2412 (1973).

10) Gottlieb H. E., Kotlyar V., Nudelman A., J. Org. Chem., 62, 75127515 (1997).

11) Corey E. J., Suggs J. W., Tetrahedron Lett., 16, 2647-2650 (1975).

12) O'Brien J., Wilson I., Orton T., Pognan F., Eur. J. Biochem., 267,
$5421-5426$ (2000).

13) Hieda T., Mikami Y., Obi Y., Kisaki T., Agric. Biol. Chem., 47, 243250 (1983).

14) Su W. C., Fang J. M., Cheng Y. S., Phytochemistry, 37, 1109-1114 (1994).

15) Kashiwada Y., Nonaka G. I., Chem. Pharm. Bull., 32, 3501-3517 (1984). 